\title{
鉄骨骨組地震応答解析のための耐力劣化を伴う簡易部材モデル A SIMPLIFIED MODEL OF STEEL STRUCTURAL MEMBERS WITH STRENGTH DETERIORATION USED FOR EARTHQUAKE RESPONSE ANALYSIS
}

\author{
孟 令 樺*, 大井謙一**, 高梨晃一*** \\ Linghua MENG, Kenichi OHI and Kohichi TAKANASHI
}

\begin{abstract}
In this papaer, inelastic portion of steel beam-columns are modeled as a simple mechanism composed of inelastic bars and a shear panel. A hysteresis rule for the bar behaviors is also proposed in consideration of strain-hardening, softening due to Bauschinger's effect, and resistance deterioration due to local buckling failure as well.

The parameters of the model are calibrated to the results of monotonic loading tests on $\mathbf{H}$. shaped and box-shaped members. Then the response analysis based on the model was performed and compared with the results of the on-line earthquake response tests. It was confirmed that their global responses were well predicted by the present model.
\end{abstract}

Keywords : steel frame, local buckling, analytical model, hysteresis rule, responese analysis 鉄骨骨組，局部座屈，解析モデル，履歴則，応答解析

$\S 1$. 序

構造物の地震時における弾塑性挙動を把握すること は, 終局限界状態設計法を構築する上で最も重要である。 骨組の終局限界状態に至るまでの弾塑性挙動を数値解析 的に追跡するために，その終局限界状態が左右される主 な要因を考慮できる解析モデル，解析方法の構築が必要 となる。例えば，転倒モーメントによって生じる変動軸 力による部材耐力の変化, $P-\Delta$ 効果ならびに部材板要 素の局部座屈による耐力劣化等の要因が挙げられる。

局部座屈を考慮した鋼構造部材の曲げ変形挙動および その解析モデルに関する研究がすでに数多くなされてい る。全体挙動を直接モデル化するもの ${ }^{2)}$ 加，部材を要

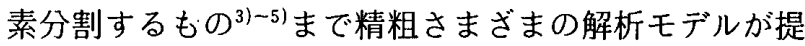
案されているが，骨組解析への適用性・計算効率等の点 で一長一短がある。

本論文ではまず，(1) 骨組の部材が弾性要素と弾塑 性要素から成ると仮定し, 複数の軸方向履歴ばねとせん 断ばねを用いて弾塑性要素の挙動を表現するという解析 モデルを提示する(Fig.1)。なお弾塑性ヒンジ領域と 嶨体とから成る解析モデルについて松井らの提案があ

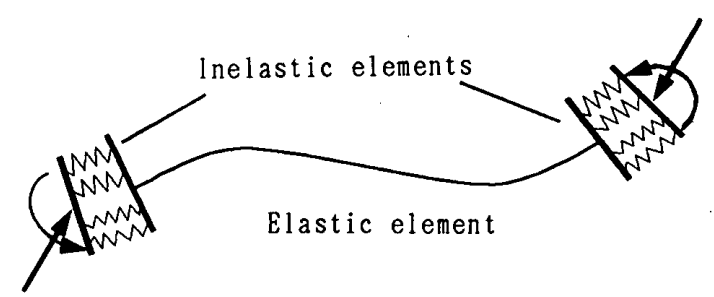

Fig. 1 Modeling of steel structural member

る6)。本論文ではさらに, $(2)^{\circ}$ 繰返し荷重を受ける鋼 構造骨組の弾塑性挙動に影響を大きく及ぼす材料のひず み硬化による耐力上昇, 局所不安定現象に上る耐力劣化 および剛性の軟化現象等を考慮した履歴ばねの復元力特 性モデルを提案する。また，（３）実地震波に対して行 われた数多くの骨組の弾塑性応答実験結果を用いて，提 示した解析モデルおよび復元力特性モデルの信頼性を実 証する。

\section{§2. 解析骨組のモデル化}

$\S 2.1$ 基本仮定

梁・柱の任意危険断面を中心として配置する弾塑性要

\footnotetext{
本論文の一部は既に文献 1）に発表した。

* 株式会社フジタ技術研究所 研究員・博士 (工学 $)$

* 東京大学生産技術研究所 助教授・博士 (工学)

*** 東京大学生産技術研究所 ·教授・博士 (工学)
}

Research Engineer, Technical Research Institute Fujita Corporation, Dr. Eng.

Assoc, Prof., Institute of Industrial Science, Univ. of Tokyo, Dr. Eng.

Prof., Institute of Industrial Science, Univ. of Tokyo, Dr. Eng. 

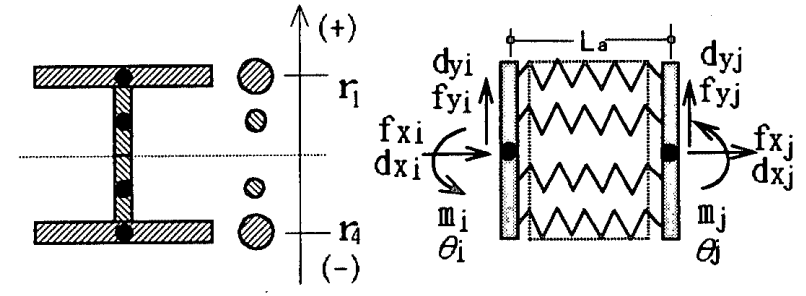

Fig. 2 Inelastic element composed of bar-springs and shear panel
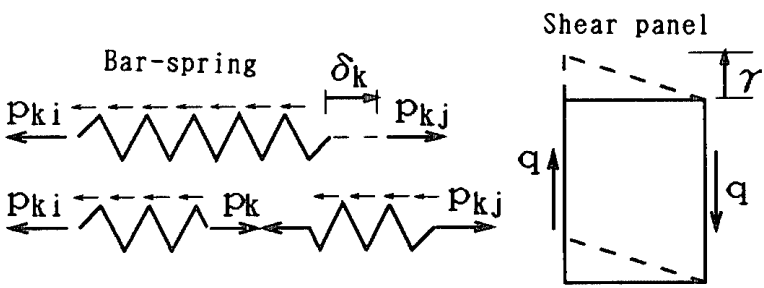

Fig. 3 Internal forces and deformations of bar-springs and shear panel

素を次のように複数の履歴ばねでモデル化する（Fig.2 を参照)。

（1）弾塑性要素断面は平面保持の仮定が成立するもの とする。部材の塑性化領域の広がりまたは板要素の局部 座屈部分長さを考虑して弾塑性要素の長さ $L_{a}$ を決め る。

（2）材料の非線形性は, 弾塑性要素の両端を結ぶ複数 の履歴ばねの復元力特性を与えることによって表現され る。また, 必要に応じて板要素の局部座屈後の挙動や接 合部の滑り等を考慮した履歴特性も取り入れられる。

（3）弾塑性要素は，両端に結ばれる 4 つの軸方向履歴 ばねと 1 つのせん断履歴ばねからなるものとする。複数 の軸方向履歴ばねによって変動軸力および変動曲げモ一 メントに対する弾塑性要素の挙動が表現される。なお, せん断履歴ばねは，軸方向ばねとは独立に扱うことにす る。

（4）弾塑性要素端部の移動による幾何学的非線形性 は，全体座標系への変換マトリックスを step by stepに 更新することによって考虑される。一方, 要素内部の変 形による幾何学的非線形性は考慮しない。

なお,弾性要素については通常の弾性梁要素を用いる。 $\S 2.2$ 弾塑性要素の定式化

Fig. 2 に示すように弾塑性要素 $i j$ は 4 つの軸ばねと

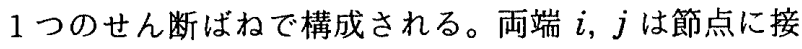
続される。節点 $i$ (左側) と節点 $j$ (右側) を結ぶ線を 基線（部材軸線）とし, 軸方向履歴ばねは基線と平行に 配置されるものとする。また，部材の断面を 4 要素に分 割し,各軸ばねをその面積要素の中心に置くことにする。 軸ばねの基線からの位置を座標で表し， $r_{n}(n=1,2$, 3，4）上する。ただし，Fig. 2 に示す場合，基線の上側
にあるものを正とする。

弾塑性要素端の力と変位を Fig. 2 に示されるように 表し，次のようにベクトルで記する。

$$
\begin{aligned}
& \{\boldsymbol{f}\}=\left(f_{x i}, f_{y i}, m_{i}, f_{x j}, f_{y j}, m_{j}\right)^{r} \ldots \\
& \{\boldsymbol{d}\}=\left(d_{x i}, d_{y i}, \theta_{i}, d_{x j}, d_{y j}, \theta_{j}\right)^{r} \ldots
\end{aligned}
$$

また, 弾塑性要素内部のばねの力と変形を Fig. 3 に 示されるように表し，次のようにベクトルで記する。

$$
\begin{aligned}
& \{\boldsymbol{p}\}=\left(p_{1}, p_{2}, p_{3}, p_{4}, q\right)^{T} . \\
& \{\boldsymbol{\delta}\}=\left(\delta_{1}, \delta_{2}, \delta_{3}, \delta_{4}, \gamma\right)^{T} \ldots
\end{aligned}
$$

ここに, $p_{k}$ : 軸ばね $k$ の中央における軸力

$q$ : せん断ばねにおけるせん断力

$\delta_{k}:$ 軸ばね $k$ の変形

$\gamma:$ せん断ばねの変形

弾塑性要素内部の力と要素端の力の釣合い関係式およ び要素内部の変形之要素端の変位の関係式は, 次の式

（5）および式（6）によって表すことができる。

$$
\begin{aligned}
& \{\boldsymbol{f}\}=[\boldsymbol{c}]\{\boldsymbol{p}\} \\
& \left.\{\boldsymbol{\delta}\}=[\boldsymbol{c}]^{T} \mid \boldsymbol{d}\right\}
\end{aligned}
$$

ここに, [c]は接続行列であり，

$$
[\boldsymbol{c}]=\left[\begin{array}{ccccc}
-1 & -1 & -1 & -1 & 0 \\
0 & 0 & 0 & 0 & 1 \\
r_{1} & r_{2} & r_{3} & r_{4} & L_{a} / 2 \\
1 & 1 & 1 & 1 & 0 \\
0 & 0 & 0 & 0 & -1 \\
-r_{1} & -r_{2} & -r_{3} & -r_{4} & L_{a} / 2
\end{array}\right]
$$

と表される。

釣合い式（5）を導出する際, 弹塑性要素の $i$ 端と $j$ 端を結ぶ軸線の中央点で軸線と直交する面において要素 を切断し，釣合いを考えたのであり，各軸ばね中央の軸 力 $p_{k}$ の切断面における作用位置は, 最初 (変形前) の 位置 $r_{\kappa}$ と変わらないものと仮定している。

弾塑性要素の力と変位の関係式は

$$
\{\Delta \boldsymbol{f}\}=[k]\{\Delta \boldsymbol{d}\}
$$

で与えられる。 $[\boldsymbol{k}]$ は弾塑性要素の増分間の剛性行列で あり，次式から求められる。

$$
\begin{aligned}
& {[\boldsymbol{k}]=[\boldsymbol{c}]\left[\boldsymbol{k}^{*}\right][\boldsymbol{c}]^{T}} \\
& \text { ここに, }\left[\boldsymbol{k}^{*}\right]=\left[\begin{array}{ccccc}
k_{1} & & & & 0 \\
& k_{2} & & & \\
& & k_{3} & & \\
& & & k_{4} & \\
& 0 & & & k_{s}
\end{array}\right]
\end{aligned}
$$

$k_{n}^{*}(n=1,2,3,4)$ および $k_{s}$ は，各軸ばねおよびせん 断ばねの増分間剛性である。

式（9）を具体的に書くと, 


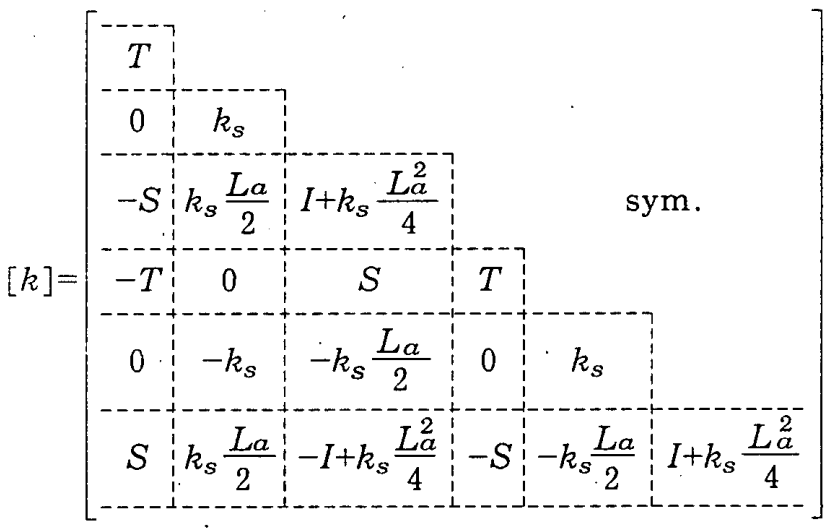

$(9)^{\prime}$

ただし $, T=\sum_{n=1}^{4} k_{n}^{*}, \quad S=\sum_{n=1}^{4} k_{n}^{*} r_{n}, \quad I=\sum_{n=1}^{4} k_{n}^{*} r_{n}^{2}$

となる。

\section{§3. 履歴ばねの復元力特性}

鋼構造部材・骨組の復元力特性モデルについては, 既 に数多く提案されている。大別すると，区分的に線形型 のモデルと何かの関数で表される滑らかなモデルに分類 できる。

区分的に線形型のモデルとしては，古くから使われて いる Bi-linear モデル, Tri-linear モデルがある。また， 加藤・秋山齐 3 は本の直線で構成されるスケルトンに基 づく履歴則を提案している。この履歴則の基本は，任意 の変形履歴下の荷重変形関係を順次つなぎ合わせて得ら れるものは単調 1 方向荷重下の荷重一変形関係に一致す ること,および弾性勾配は不変であるということである。 この履歴則は簡明であるが, 繰り返しによる剛性の軟化 が考慮されていない。

一方, 連続関数で表される滑らかな復元力特性モデル として, Ramberg-Osgood モデル および 1 つの微分方 程式の形で表す微分方程式型モデルが挙げられる。こ れらの復元力特性モデルは，すでに多くの研究者に応用 されており，その有用性が指摘されている（例えば，文 献 10)，11）。しかし, これらの復元力特性モデルでは, 部材の局部的不安定等による急激な耐力劣化を表現する ことは困難であ.る。

上述の既往研究を踏まえ，鋼材のひずみ硬化による繰 返し時の耐力の上昇, 局部的な不安定等による耐力の劣 化および剛性軟化効果等の現象を配慮して, 前節で述べ た弾塑性要素を構成する軸方向履歴ば秝の復元力特性モ デルを提案する。

(1) スケルトン曲線

引張り軸力下と圧縮軸力下のスケルトン曲線を, Fig.4(a) に示しているようにそれぞれ三本の直線を用 いて表す。引張側は弾性域(1)，ひずみ硬化域(2)っおよ び最大強度域(3) からなり，圧縮側は弾性域(1)、ひずみ

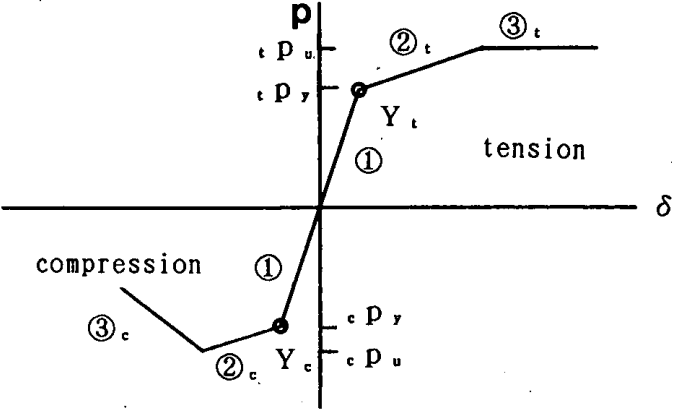

(a) Initial skeleton curves

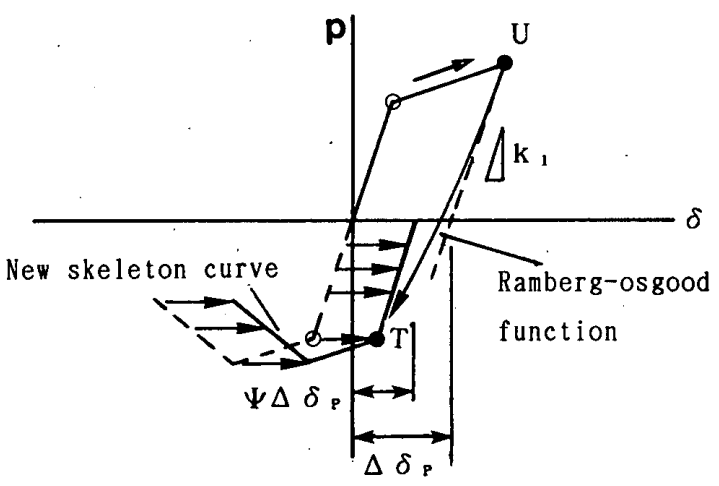

(b) Shift of skeleton curve and unloading path

Fig. 4 Hysteresis rule for bar-springs

硬化域(2) および劣化域(3) からなると仮定する。 （2）スケルトン曲線における目標点とその更新 引張側と圧縮側において履歴曲線の目指す点, すなわ ち, 目標点を一つずつ定義する。初期目標点は, 弾性限 点 $Y_{t}, Y_{c}$ とする。載荷点が弾性限を過ぎてスケルトン 上で移動する場合には, Fig.4(b) に示しているように, 載荷点側の目標点を載荷点と同時に移動させ,更新する。 このとき, 反対側の目標点をそのスケルトン曲線ととも に, 載荷点の経験する塑性変形量 $\Delta \delta_{\rho}$ の $\Psi$ 倍だけ変形 軸に沿って移動させる。除荷後の履歷曲線は，この二つ の目標点を参照して決められる。『の値を 0 とすると, スケルトン部分以外は通常の Ramberg-Osgood モデル となる。また， $\Psi$ の值を 1 とすると，加藤・秋山モデ ルに一致し, スケルトン上の目標点を, 載荷点が経過し た塑性変形量の全值移動させることになる。実際の鋼部 材の履歷はこの両極端の中間に位置すると考える。

鋼材の応力ーひずみの履歴曲線においては, いわゆる Prandtl の法則が満足され，逆方向の塑性変形を受けた 後に再負荷した場合, 再負荷の方向之逆方向に最後の除 荷した点を通るという特徵がある。提案した復元力特性 モデルは，スケルトン曲線上においてのみ, Prandtl の 法則を満足している。

（3）履歴曲線関数とその定め方

除荷が起こる度にこの除荷点とこれからの指向方向に ある目標点を用いて履歴曲線を定める必要がある。ここ では, Ramberg-Osgood 関数を参照して履歴間の荷重 $p$ 


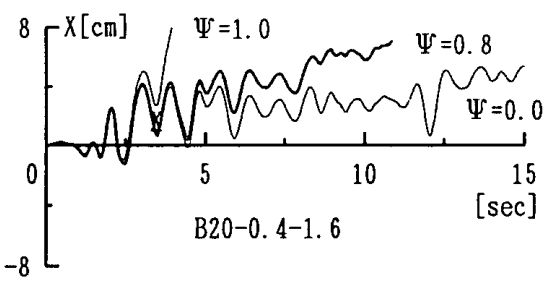

Fig. 5 Response analyses using different hysteresis rules

と変形 $\delta$ の関係を次式で与える。

$$
\left(p-p_{U}\right)\left[a+b\left|p-p_{v}\right|^{r-1}\right]=\delta-\delta_{v}
$$

$p_{U}$ と $\delta_{U}$ は現在除荷点における荷重と変形であり, $a$ と $b$ は係数である。指数 $r$ の変化によって履歴曲線の 丸みを変えることができる。式（10）の両辺を $\delta$ に関 して微分すると，

$$
\frac{d p}{d \delta}=\frac{1}{a+b r\left|p-p_{u}\right|^{r-1}}
$$

が得られる。これは履歴ばねの接線剛性 $k^{*}$ となる。

次の $2 つ の$ 条件を用いて係数 $a, b$ を定める。

（i ）現在の除荷点における接線剛性はスケルトン曲線 の初期弾性勾配に等しいこと。

(ii）目標点を通ること。

初期弾性勾配を $k_{1}$, 目標点における荷重と変形を $p_{T}, \delta_{T}$ とする。上記の $2 つ の$ 条件を式 (11) と式 (10) に代入して整理すると,

$$
\begin{gathered}
\begin{array}{c}
a=\frac{1}{k_{1}} \\
b=\frac{1}{\left|p_{T}-p_{U}\right|^{r-1}}\left(\frac{1}{k_{U T}}-\frac{1}{k_{1}}\right)
\end{array} \\
\text { ただし, } k_{U T}=\frac{p_{T}-p_{U}}{\delta_{T}-\delta_{U}}
\end{gathered}
$$

$k_{U T}$ は現在除荷点と目標点間の履歴曲線の割線勾配とな る。

式（12）を式（11）に代入すると, 履歴ばねの接線剛 性は式（13）で表される。

$$
k^{*}=\frac{k_{1} k_{U T}}{k_{U T}+r\left(k_{1}-k_{U T}\right)\left|\frac{p-p_{U}}{p_{T}-p_{U}}\right|^{r-1}}
$$

目標点を更新する時に用いた係数 $\Psi$ が応答挙動に及 ぼす効果を示す例として, Fig. 5 には $\Psi=0.0$ (Ramberg-Osgood モデル)， $\Psi=0.8$ および $\Psi=1.0$ (加 藤・秋山モデル）とした場合の応答解析結果を示してい る。 $\Psi=1.0$ の場合は, 応答変位が最も早期に発散した。 なお，解析例は§5 で述べる梁・柱のオンライン地震応 答実験の一例を解析したものである。

\section{§4. 地震応答解析法}

地震応答解析において無減衰の場合の水平振動方程式 は次式で表される。

$$
[\boldsymbol{M}] \mid \ddot{\boldsymbol{X}}\}+\left\{\boldsymbol{F}_{\boldsymbol{v}}\right\}=-[\boldsymbol{M}]\{\mathbf{1}\} \ddot{Y}
$$

ただし， $\{\boldsymbol{X}\}$ ：質量のある節点の水平変位ベクトル

$\left\{F_{v}\right\}$ : 水平外力に対する骨組の復元力バクトル $\ddot{Y}:$ 地震動加速度

$$
[\boldsymbol{M}]: \text { 質量行列 }
$$

“..” : 時間に対する 2 階微分

ここでは，骨組の増分方程式を次式のように表す。

$$
\left\{\begin{array}{l}
\Delta F_{V} \\
\Delta F_{\theta}
\end{array}\right\}=\left[\begin{array}{ll}
K_{1} & K_{2} \\
K_{3} & \mathbb{K}_{4}
\end{array}\right]\left\{\begin{array}{c}
\Delta \mathbb{X} \\
\Delta \theta
\end{array}\right\}
$$

ただし， $\{\theta \mid$ : 力の拘束のある方向の節点変位ベクトル

$\left\{\boldsymbol{F}_{\theta}\right\}:\{\boldsymbol{\theta} \mid$ に対応する節点荷重ベクトル

中央差分法を用いて, 運動方程式（14）を解くと,

$$
\left.\{\Delta \boldsymbol{X}\}^{i}=\{\Delta \boldsymbol{X}\}^{i-1}-(\Delta t)^{2} \cdot\left([\boldsymbol{M}]^{-1} \mid \boldsymbol{F}_{\boldsymbol{v}}\right\}^{i}+\{\mathbf{1}\} \ddot{Y}^{i}\right)
$$

ここで, $\left\{\left.\Delta \boldsymbol{X}\right|^{i}=\{\boldsymbol{X}\}^{i+1}-\{\boldsymbol{X}\}^{i}\right.$

$\Delta t:$ 時間刻み

になる。式（16）の右辺にあるのはすべて $i$ ステップ以 前の情報で，既知である。したがって，それを用いて（ $i$ +1）ステップの変位応答が解かれる。

節点の移動による幾何学的非線形は，増分解析におい て, 要素端部の力・変形関係が骨組の全体座標係へ変換 するときに用いた座標変換行列を，各ステップにおける 節点位置に基づいて更新することによって考慮される。

弾塑性要素が構成される複数の履歴ばねの魝性は, 変 位増分法による骨組の弾塑性数値解析中, 頻繁に变化し ていると予測される。一般に増分量が未知の場合，この ような㓮性をある履歴則のもとで磼定することは困難で ある。近似值として現在の弾塑性状態のもとでの履歷ば ねの接線剛性を用いている。この場合，現在の増分区間 の状態が変わると誤差が生じる。このような誤差によっ て節点に生じた不釣合力の累積を避けるため，現時点に おいて生じた不釣合力を次ステップで修正する方法を用 いる。具体的には，現時点に生じた不釣合力を次ステッ プで負の節点外力として節点荷重ベクトル $\{\boldsymbol{F}\}$ に加え $3^{12)}$ 。

数值解析の流れを以下に示す。

（1）式（16）を用いて $\{\Delta X\}^{l}$ を計算する。

（2）式（15）を用いて $\{\Delta X\}^{i} よ り\{\Delta \theta\}^{i}$ を求める。 このとき，剛性行列の一部分だけを利用する。さらに上 述の不釣合力の修正法を用いて， $\left\langle\left.\Delta \theta\right|^{i}\right.$ を次式で表すこ とができる。

$$
\left\{\left.\Delta \theta\right|^{i}=\left[K_{\mathbf{4}}\right]^{-1}\left(\left|\boldsymbol{F}_{\theta}\right|^{0}-\left\{\left.\boldsymbol{F}_{\theta}\right|^{i}-\left[\boldsymbol{K}_{3}\right] \mid \Delta \boldsymbol{X}\right\}^{i}\right)\right.
$$

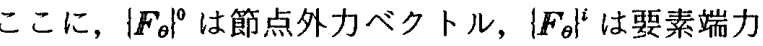

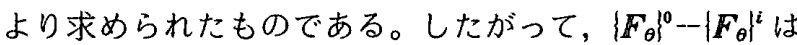
$i$ step において生じた不釣合力となる。

（3）節点変位增分 $\left\{\begin{array}{l}\Delta X \\ \Delta \theta\end{array}\right\}^{c}$ より座標変換によって部 材端変位増分 $\{\Delta \boldsymbol{d}\}^{i}$ を求め, さらに, 式 $(6)$ 加ら弾塑 性要素内部の変形増分 $\{\Delta \boldsymbol{\delta}\}$ を求める。 
(4) 弾塑性要素の履歴ばねの復元力ベクトル $\{\boldsymbol{p}\}^{i+1}$ を, §3で述べた復元力特性モデルから求める。

（5）式（5）を用いて要素端力ベクトル $\left\{\boldsymbol{f}^{i+1}\right.$ を求め る。さらに座標変換を通して $(i+1)$ step の全節点力 ベクトル $\left\{\boldsymbol{F}_{V}\right\}^{i+1}, \quad\left\{\left.\boldsymbol{F}_{\theta}\right|^{i+1}\right.$ を求めることができる。

以上（1）（ 5 ）を繰り返すことによって運動方程式 (14) が解かれる。

\section{§5. 解析結果と実験結果の比較}

\section{$\S 5.1$ 実験の概要}

本節では，鉄骨 H形断面，箱形断面の梁・柱試験体と 3 層骨組模型に対して行われた静的単調載荷実験および オンライン地震応答実験の結果 ${ }^{13)-15)}$ を用いて，前節ま でに述べた鋼構造平面骨組の弾塑性解析法, 復元力特性 モデルの有用性を実証する。本論文において利用した実 験の概要を簡単に述べる。

\section{1) 試験骨組}

$\mathrm{H}$ 形断面の梁・柱試験体は，フランジに板厚 $9 \mathrm{~mm}$, ウェブに板厚 $6 \mathrm{~mm}$ の圧延板を使用して隅肉溶接で制作 されたものであり，箱形断面の試験体は $6 \mathrm{~mm}$ の圧延板 を使用してかど溶接で製作されたものである。また，す べての試験体の強軸まわりの細長比が 20 程度であり， $\mathrm{H}$ 形断面の片フランジの幅厚比が 10,8 と, 箱形断面 幅厚比が 40,30 と 20 のそれぞれ 3 種類である。各試験
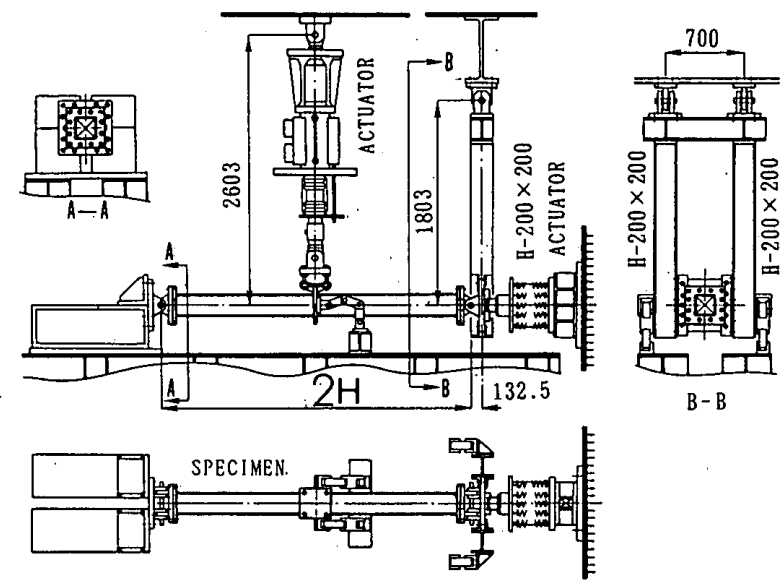

Fig. 6 Test setup of beam-column. specimens

Table 1 Properties of members

\begin{tabular}{|l|l|l|l|c|c|}
\hline $\mathrm{No}_{\mathrm{o}}$ & $\mathrm{t}_{\mathrm{t}}$ & $\mathrm{t}_{\mathrm{w}}$ & $2 \mathrm{~b}$ & $\mathrm{~b} / \mathrm{t}_{\mathrm{t}}$ & $\mathrm{H}$ \\
\hline $\mathrm{H}-10$ & 9 & 6 & 180 & 10 & 1600 \\
$\mathrm{H}-8$ & 9 & 6 & 144 & 8 & 1300 \\
$\mathrm{H}-6$ & 9 & 6 & 108 & 6 & 1000 \\
\hline \hline $\mathrm{No}$ & $\mathrm{t}$ & $\mathrm{B}$ & $\mathrm{B} / \mathrm{t}$ & $\mathrm{H}$ & \multicolumn{1}{|}{} \\
\hline $\mathrm{B}-40$ & 6 & 240 & 40 & 2000 \\
$\mathrm{~B}-30$ & 6 & 180 & 30 & 1300 \\
$\mathrm{~B}-20$ & 6 & 120 & 20 & 1000 \\
\hline
\end{tabular}

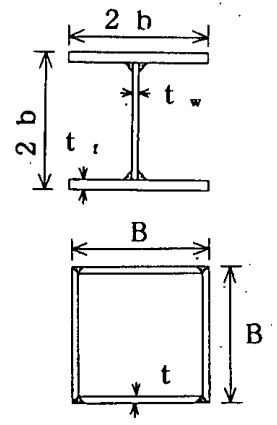

体の諸元を Table 1 に示す。試験体は断面形状と幅厚比 の組み合わせで 6 種類に分類され，それぞれ $\mathrm{H}-10, \mathrm{H}-8$, $\mathrm{H}-6$ および B-40, B-30，B-20 と称する。

実験のセットアップ状況はFig. 6 に示すように, 一 端がピン支持, 他端がピンローラ支持である。試験体に 一定の軸力を加え, さらに中央で鉛直方向の載荷を行っ た。

3 層骨組模型試験体は·Fig. 7 に示しているように, 1 スパン 1 構面のラーメン骨組模型である。試験体は試験 床に高力ボルトで緊結され，各階の梁の材軸位置に水平 載荷が行われた。

また，すべての実験において試験体の構面外座屈が生 じないようにしている。試験体に使用した鋼材は，最近 開発された降伏比の低い 60 キロ級高張力鋼である。鋼 材の応力ーひずみ関係を Fig. 8 に示している。

\section{2）実験の概要}

梁・柱の静的単調載荷実験とオンライン地震応答実験 は，軸力のない場合と軸力のある場合（軸力比 $n_{y}=0.4$, ただし B-40は 0.2) のそれぞれ 12 例である。.また， 3 層骨組模型の実験は, 逆三角形分布を水平外力分布とし た静的単調比例載荷実験とオンライン地震応答実験の各 1 例である。

すべてのオンライン実験に使用した地震動波形は 1940 年 Imperial Valley 地震の際, El Centro で観測さ
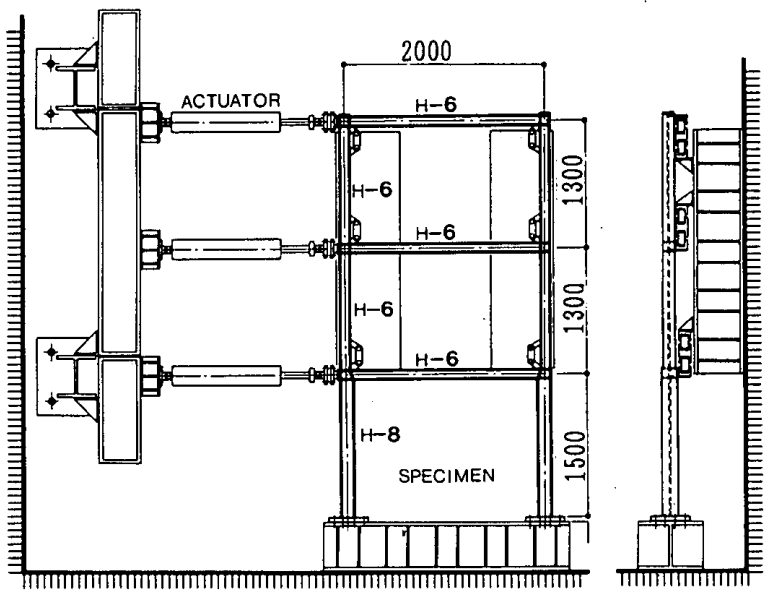

Fig. 7 Test setup of 3-story frame model

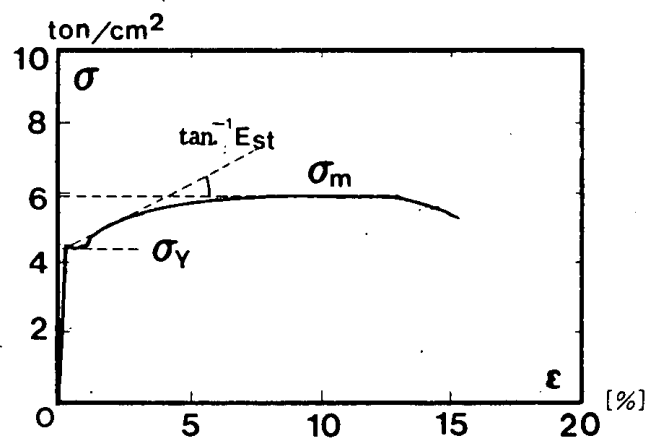

Fig. 8 Typical stress-strain curve of steel material 
れた記録の NS 成分の主要部分 15 秒間の加速度波であ り，実験別に単調載荷実験で得られた試験骨組の最大水 平耐力に応じて適宜に増減して用いた。原波の最大加速 度は $347.2 \mathrm{gal}$ である。また，固有周期（または 1 次固 有周期)を約 0.8 秒とした。

なお，すべての実験において，局部座屈変形が観察さ れた。

$\S 5.2$ 復元力特性モデルを定める諸パラメータ

1) 軸ばねの引張側のスケルトン曲線については，素材 の応力・ひずみ関係に基づいて降伏耐力 ${ }_{t} p_{y}$ と最大耐力 ${ }_{t} p_{u}$ を定め, 各軸ばねの受け持つ面積と弾塑性要素の長 さ $L_{a}$ から弾性域(1)の勾配 $k_{1}$ を定める。 $L_{a}$ として, 部 材断面の幅（材長の 1 割程度）と同じものを用いる。硬 化域(2)

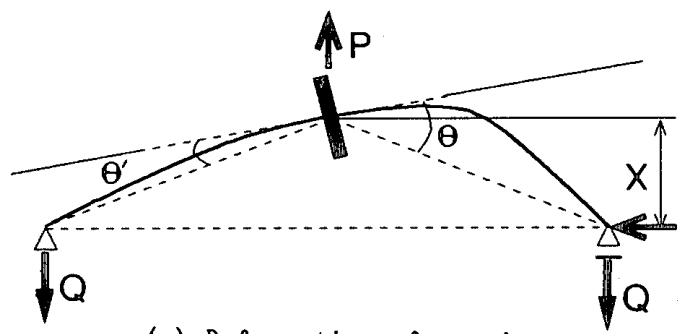

(a) Deformation of specimen

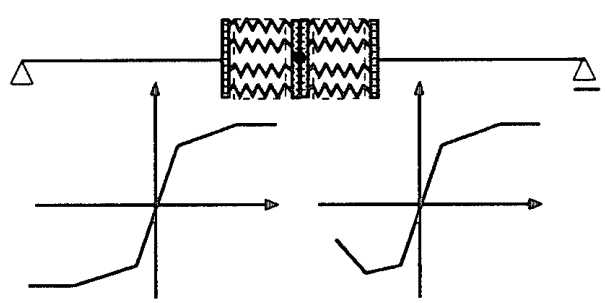

(b) Analytical model

Fig. 9 Analytical model for beam-column tests
の応力・ひずみ関係のそれと同じになるように定める。 最大耐力に達した後, 変形の進行に伴ってその耐力レベ ルを保つとし，すなわち $k_{3}$ を 0 とする。

2）軸ばねの王縮側のスケルトン曲線は，局部座屈など の影響を受けると考えて部材の形状に応じて評洒する必 要がある。また, 後に示す梁・柱の単調載荷実験の $M$ 〜 $\theta$ 関係から分かるように，軸力のある場合は最大耐力 後の耐力劣化が顕著になっている。一方, 構造物が地震 のような繰返し荷重を受ける場合，骨組を構成する各部 材，特に柱材における軸力は時々刻々変動している。そ れに応じて個々のばねの特性を変化させることは，困難 かつ煩雑である。そこで，圧縮側のスケルトン明線を定 める諸パラメータを，部材に作用する軸力に関係なく評 価するとする。具体的には，弾性勾配 $k_{1}$ と降伏耐力 ${ }_{c} p_{y}$ は引張側のスケルトン曲線のそれらと同じものとす る。硬化勾配 $c k_{2}$, 劣化勾配 $c k_{3}$ および最大耐力 ${ }_{c} p_{u}$ には, 部材断面形状のほか, 材長方向および断面内の応力分布 の勾配も影響を及ぼしている。事実，梁・柱の応力上昇 率は短柱圧縮時の応力上昇率よりかなり高いことが分 かっている ${ }^{13)}$ 。したがって短柱圧縮実験から得られた局

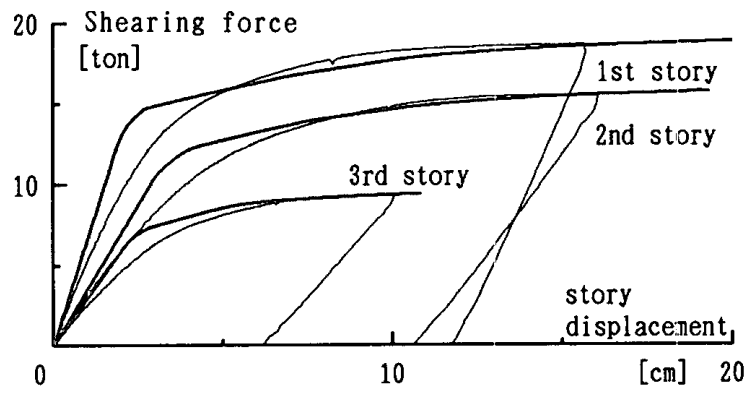

Fig. 11 Story shearing force vs. story displacement relationships of 3-story frame under monotonic loadingtested (thin curve) and computed (bold curve)
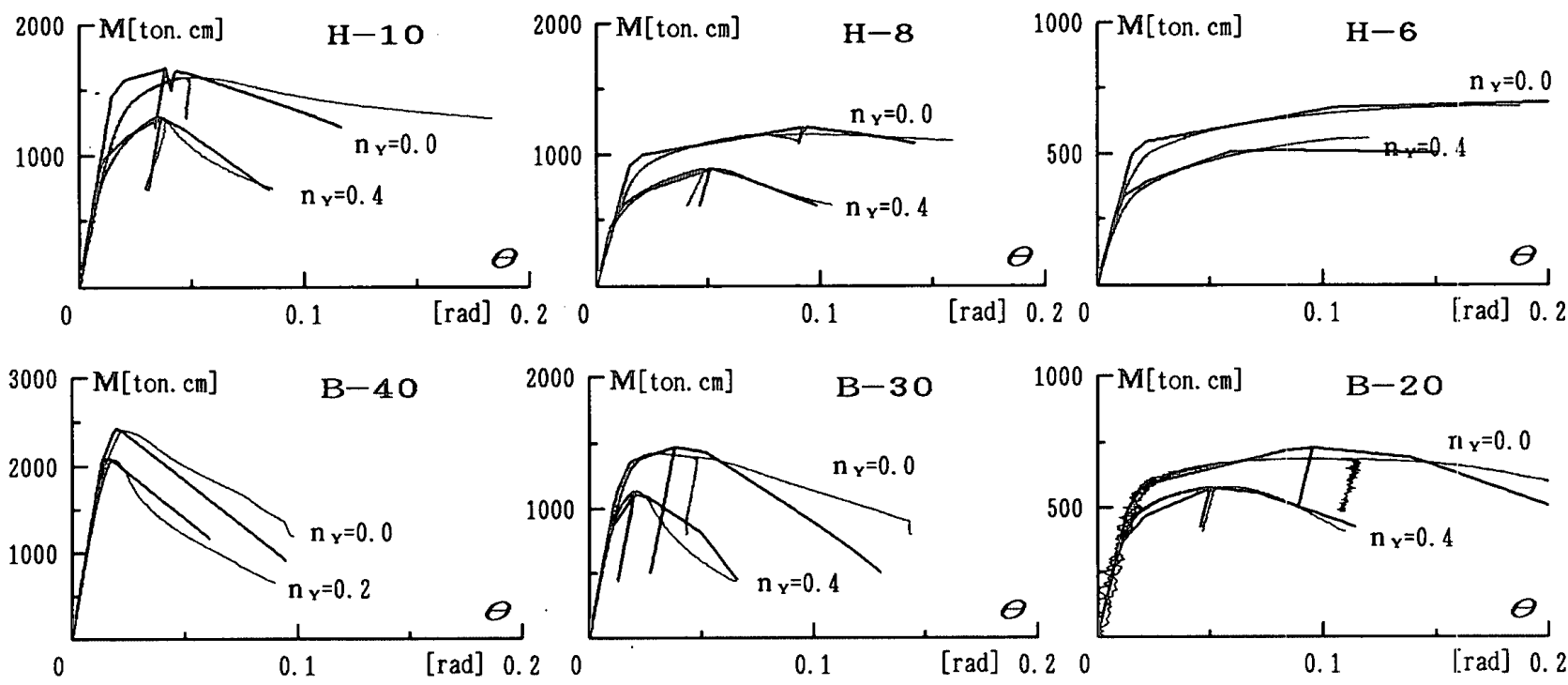

Fig. 10 Moment vs. rotation angle relationships of beam-columns under monotonic loading-tested (thin curve) and modeled (bold curve) 

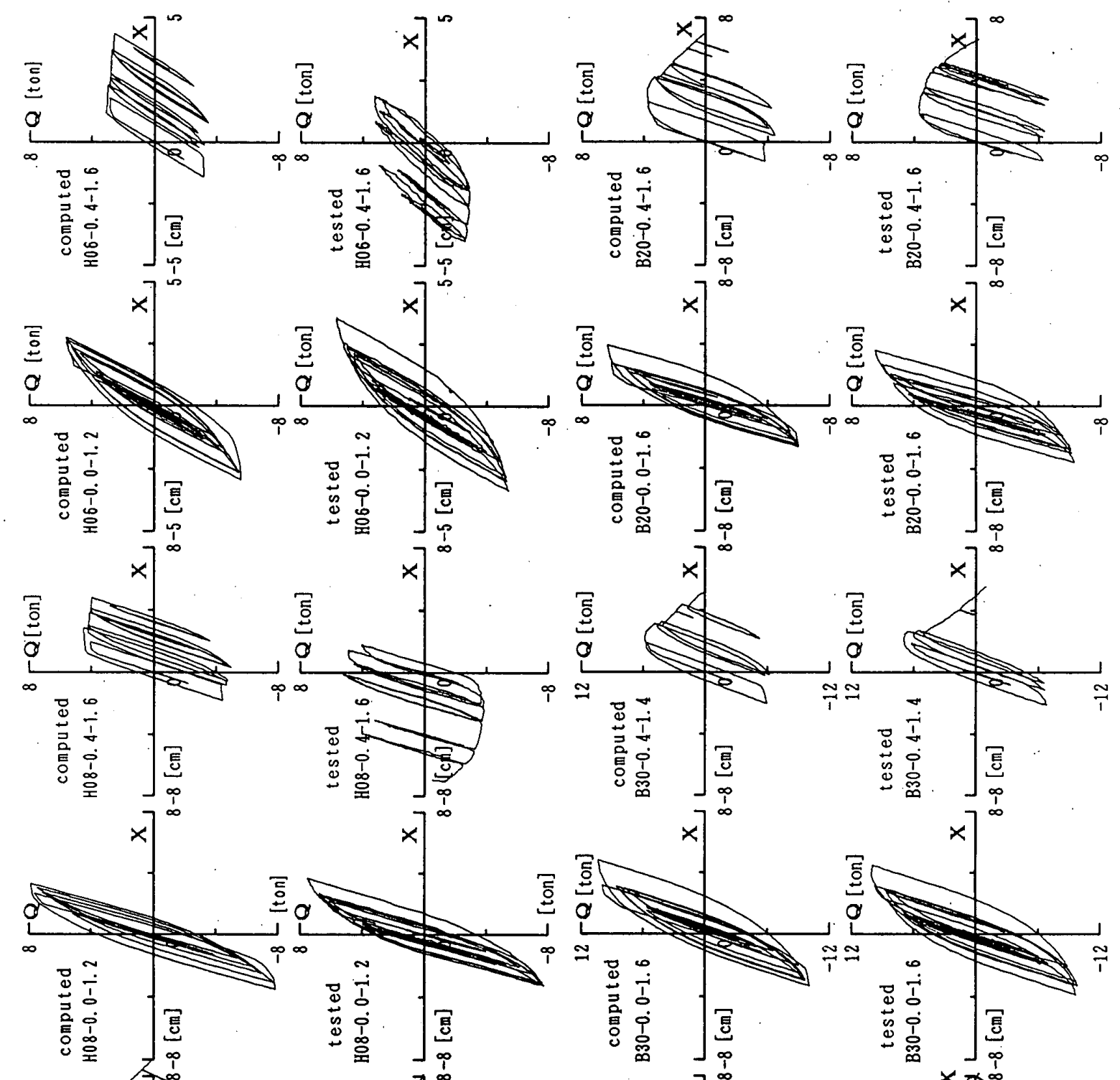

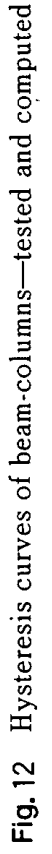

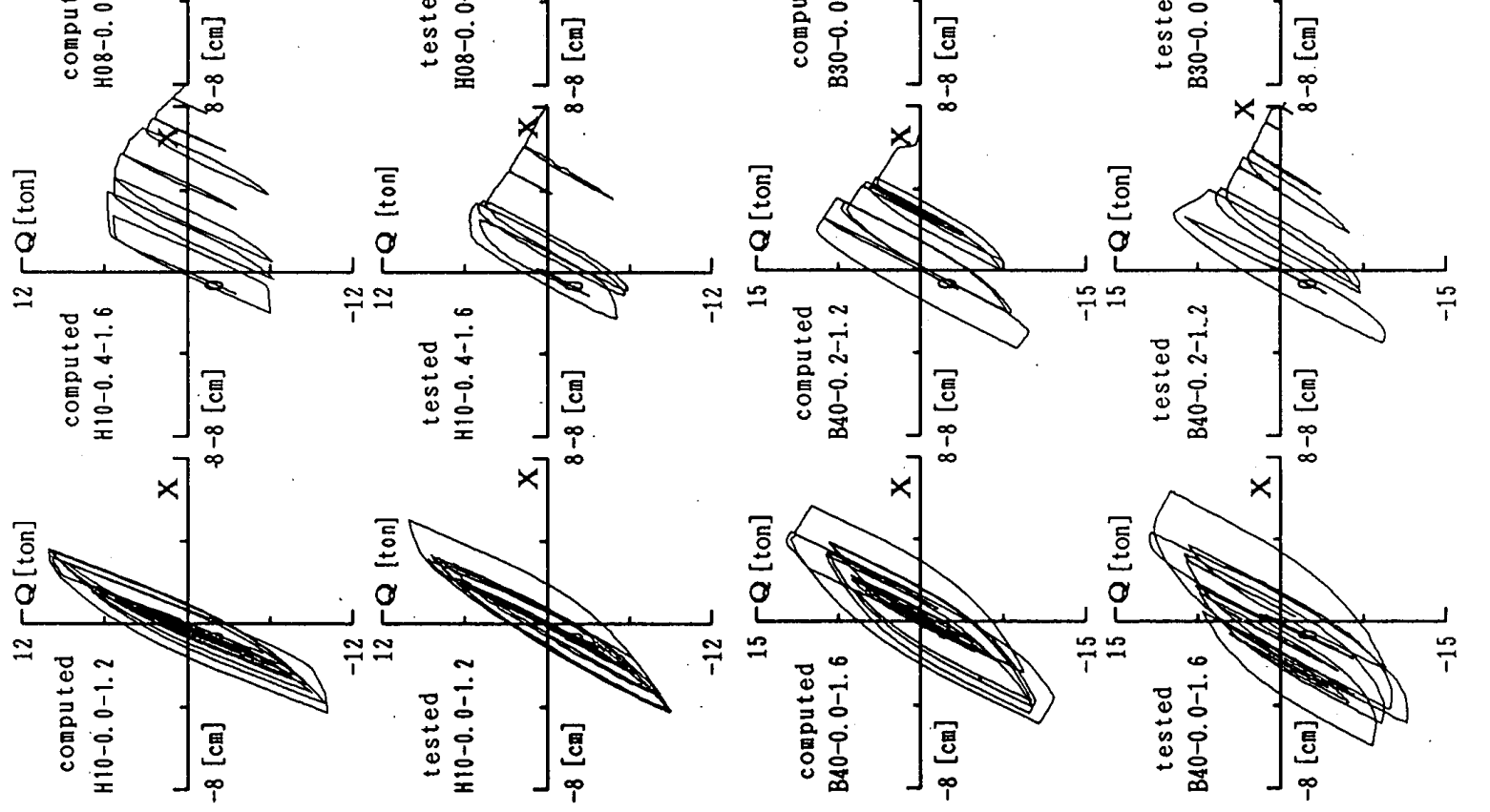


部座屈耐力や応力・ひずみ関係の劣化勾配は, $c k_{2}, c k_{3}$ および ${ }_{c} p_{u}$ を決めるために必ずしもそのまま適用できな い。ここでは梁・柱の静的単調載荷実験を分析し, 分析 結果を実験結果と対比させて試行錯誤でこれらのパラ メー夕を決めることとする。その際には, ${ }_{c} k_{2},{ }_{c} k_{3}$ の $k_{1}$ に対する比率および ${ }_{c} p_{u}$ の ${ }_{c} p_{y}$ に対する比率が各軸ばね について等しくなるようにしている。

3）履歴曲線の曲がり具合（剛性軟化の度合い）は, 目 標点を更新する時に用いる係数 $\Psi$ と指数 $r$ によって支 配される。文献 16）において H 形断面の梁・柱の繰返 し載荷実験結果に本モデルをあてはめた結果， $\Psi=0.8$, $r=5$ とすれば, 解析結果は実験結果とよく一致してい ることが示された。本論文においても同様な值とした。 4）せん断ばねを弾性とし，弾塑性要素部のウェブパネ ルのせん断剛性を $k_{s}$ とした。

\section{$\S 5.3$ 解析結果と実験結果の比較}

Fig.9(a) に示すように，曲げ荷重と軸荷重を受ける 梁・柱試験体は, 中央プレート近辺において局部座屈変 形が発生する。その後, 片方の局部來屈変形が進行する。 それに伴って中央プレートが回転し, 試験体の変形が非 対称となる。試験体局部座屈後の挙動を忠実に表現する ために，ここでは，Fig.9(b) に示すような解析モデル を用いる。つまり，中央プレートの両側に弾塑性要素を
設置し，片方の弾塑性要素においてのみ，局部坐屈を想 定するばねの復元力劣化を生じさせる。

Fig. 10 は, 静的単調載荷場合の解析結果を実験結果 と比較したものである。縦軸と横軸は, 中央プレートを 中心にして試験体を左右 2 つに分離したときのそれぞれ の材端曲げモーメント $M$ と材端回転角 $\theta$ である。図中 の太線は解析結果であり，細線は奏験結果である。これ らの図に示されるように，局部座屈が起こると，片方は 曲げ耐力劣化が生じ，片方は弾性除荷が生じている。解 析結果はこの現象をよく捉えており, 局部座屈後の挙動 を含めて実験結果をよく反映している。

3 層骨組模型実験に対する解析では，骨組のすべての 部材両端部を弾塑性要素でモデル化した解析モデルを用 いた。静的載荷解析方法としては, 水平外力の分布形と ある節点の変位増分を与えてその点の反力増分, 荷重パ ラメータの増分および他の節点変位増分を求める変位増 分制御法を用いた。この方法は, 特に骨組の不安定領域 を含む変形挙動を追跡する数值解析法として妥当である と指摘されている ${ }^{17) .18)}$ 。Fig. 11 屿層せん断力と層間変 位について解析結果と実駼結果を比較したものである。

以上, 単調載荷の解析と実験の比較によって, 各種の 部材について実験結果からあてはめた軸ばねの復元力特 性のスケルトン曲線は適切であることを確認した。
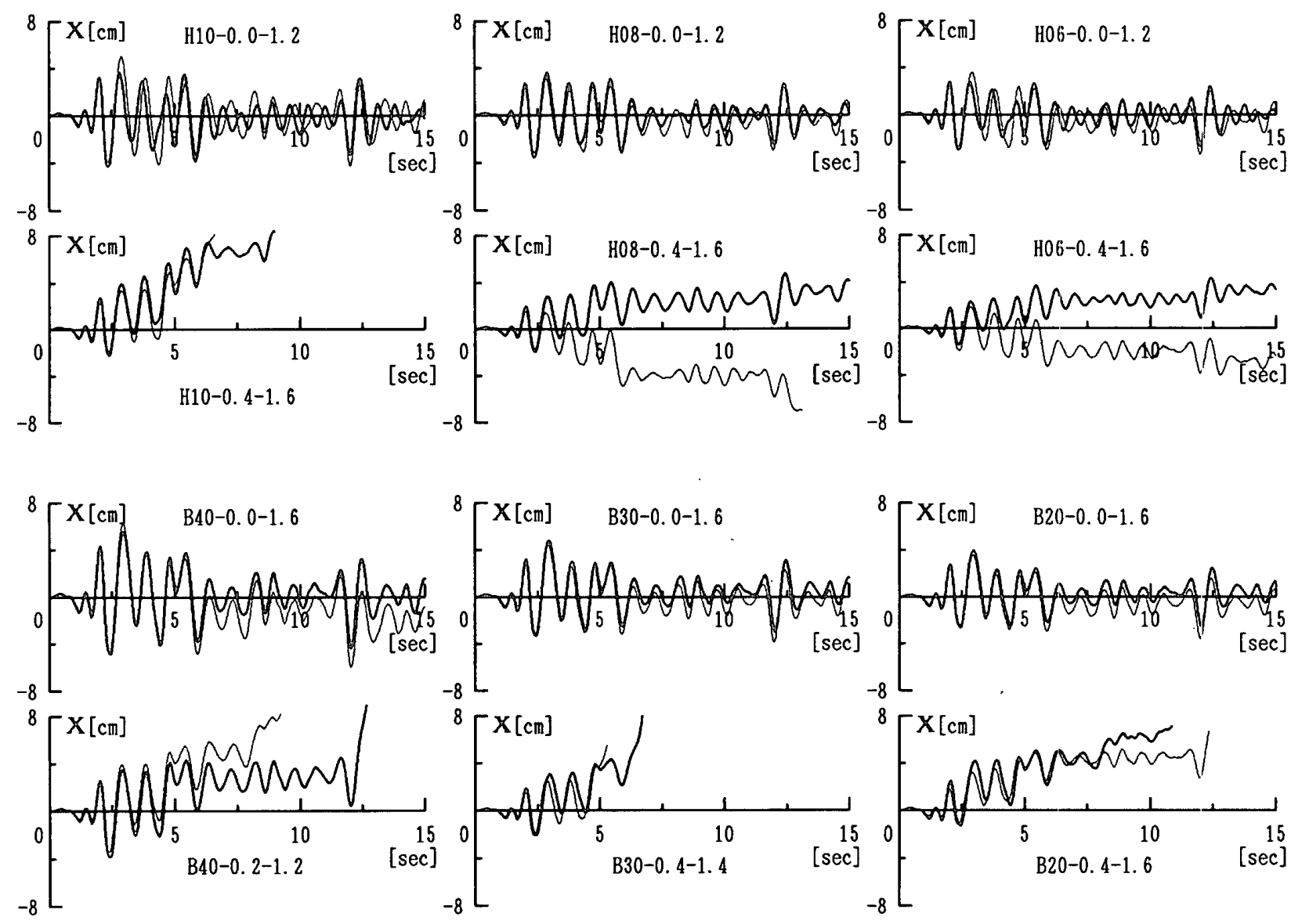

Fig. 13 Time histories of response displacements of beam-columns-tested(thin curve) and computed (bold curve) 

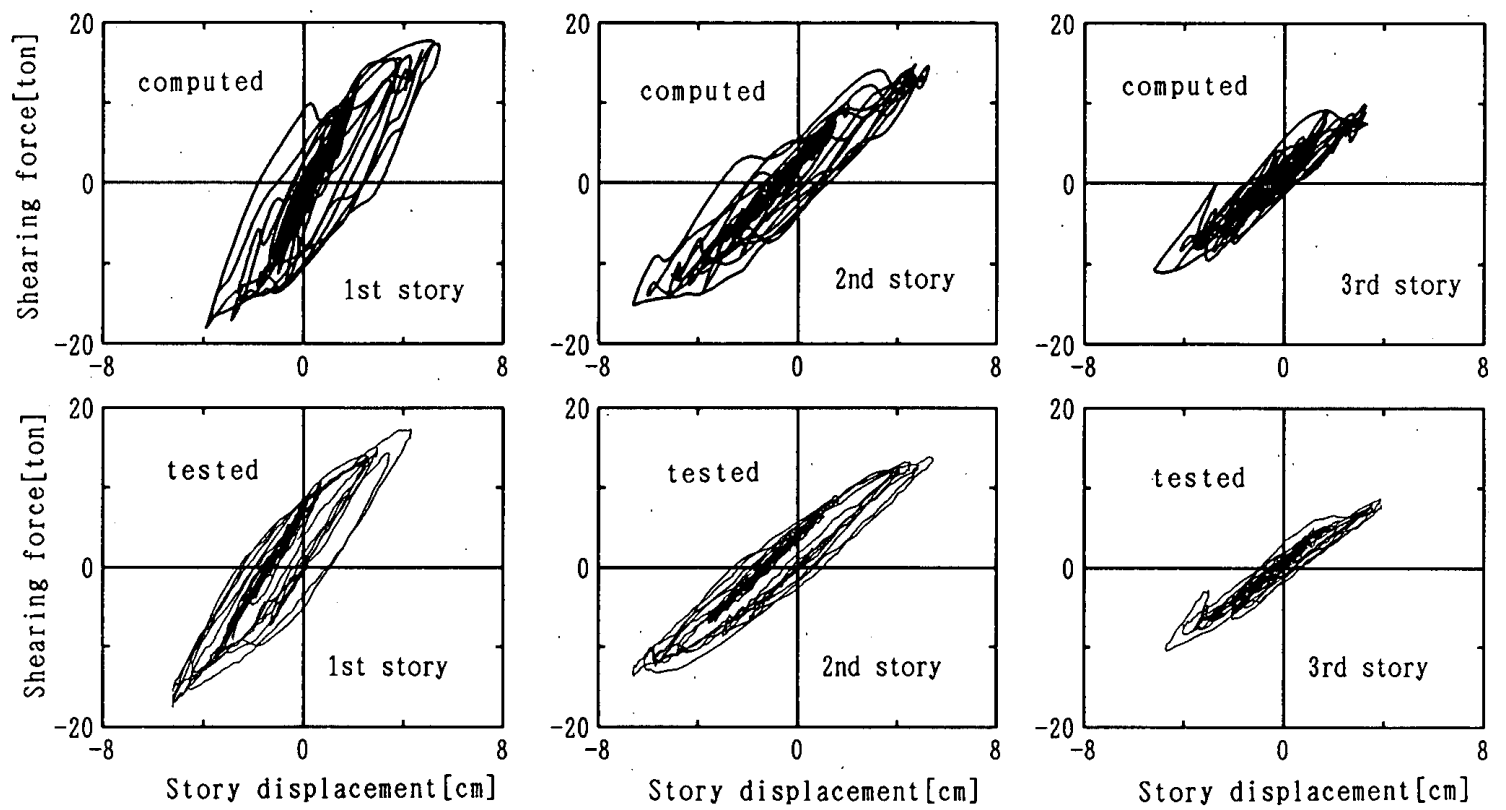

Fig. 14 Hysteresis curves of 3-story frame-tested and computed

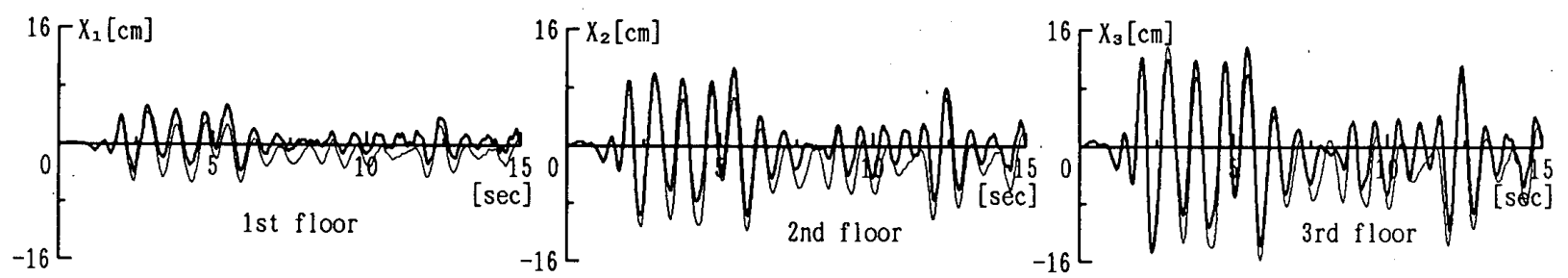

Fig. 15 Time histories of response displacements of 3-story frame-tested (thin curve) and computed (bold curve)

Fig. 12 と Fig. 13 は，梁・柱試験体に対して行われ たオンライン地震応答実験結果とそれらの解析結果を比 較したものである。Fig. 12 にせん断力と中央水平変位 の関係を示しており, Fig. 13 に中央水平変位の時刻歴 を示している。図中の解析名または実験名は, “a-b-c” の形で表しており，a に試験体の種類，b に軸力比， c に降伏加速度比（単調載荷で得られた最大水平耐力を慣 性質量で除したものを降伏加速度とし，最大入力加速度 を降伏加速度で除した値）を表している。これらの図か ら，数值解析結果は局部座屈後の挙動についてもある程 度追跡できていることが分かる。

Fig. 14 と Fig. 15 は 3 層骨組模型の応答解析結果之 実験結果を比較したものである。Fig. 14 に層せん断力 と層間変位の関係を示しており, Fig. 15 に各相対変位 の時刻歴を示している。

\section{§6. まとめ}

（1）局部座屈後の挙動を含む鋼構造骨組の弾塑性地震 応答解析のための簡易部材モデルを示した。この解析モ デルは，骨組の部材が危険断面を中心とする一定の長さ を持つ弾塑性要素と弾性要素から成ると仮定し, 弾塑性 要素を複数の履歴ばねでモデル化している。この解析モ デルの利点として，転倒モーメントによる変動軸力の影
響を簡便に考慮できること, 部材を構成する板要素の局 部座屈後の挙動を履歷ばねの復元力特性に取り入れられ ること等が挙げられる。

（2）耐力上昇・劣化，剛性の軟化等の諸現象を取り入 れた復元力特性モデルを提案した。

（3） H 形断面, 箱形断面の梁・柱および 3 層骨組模 型に対して夷施された数多くの単調載荷実験とオンライ ン地震応答実験の解析を行った。弾塑性要素における履 歴ばねの復元特性のスケルトン曲線を, 梁・柱の単調載 荷実験結果と適合するように定めれば，本論文で提案し た解析モデルを用いて鋼構造骨組の局部座屈後の挙動を 含む地震時の弾塑性挙動を追跡することができる。

謝 辞

本研究は,第一著者が東京大学に提出した学位論文「鋼 構造骨組の終局限界状態の解明」の一部である。また, 本研究は, 平成元年度文部省科学研究費補助金 - 一般研 究 (B)「鋼構造物の終局限界状態の定量化」(No. 63460170 , 研究代表者: 高梨晃一) の助成を受けた。数 多くの実験の実施にあたって，多大なご協力を頂いた東 京大学生産技術研究所 嶋脇与助- 近藤日出夫両技官, ならびに試験体の製作にご助力を頂いた新日本製鐵株式 会社に深く感謝致します。 


\section{参考文献}

1) Ohi, K., Takanashi, K. and Meng, L. H. : Multispring Joint Model for Inelastic Behavior of Steel Members with Local Buckling, Bulletin of Earthquake Resistant Structure Research Center, Institute of Industrial Science, Univ. of TOKYO, No. 24, pp. 105 114, March, 1991

2) 加藤 勉, 秋山 宏, 帯 容一：局部座屈を伴う $\mathrm{H}$ 形断 面材の変形, 日本建築学会構造系論文報告集, 第 257 号, pp. $49 \sim 58,1977$ 年 7 月

3) Climenhaga, J. J. and Johnson, R. P. : MomentRotation Curves for Locally Buckling Beams, J.S. Div., ASCE, Vol.98, No.ST 6, pp.1239 1254, June, 1972

4）三谷 勲, 牧野 稔, 松井千秋：H形鋼柱の局部座屈後 の変形性状に関する解析的研究 (その1) 単調荷重を受 ける場合, 日本建築学会構造系論文報告集, 第 296 号, pp. $37 \sim 47,1980$ 年 10 月

5）辻 文三：繰り返し荷重を受ける鋼構造物の弾望性変形 性状ならびに崩壊性状に関する研究, 京都大学学位論文, 1985 年 1 月

6) 松井千秋, 森野捷輔, 内田保博: 水平 2 方向外力を受け る鋼構造立体骨組の弾塑性性状（その1) (その 3), 日 本建築学会論文報告集, 第 319 号, 1982 年 9 月, 第 333 号, 1983 年 11 月, 第 349 号, 1985 年 3 月

7) Kato, B., Akiyama, H. : Inelastic Bar Subjected to Thrust and Cyclic Bending, Proc. ASCE, Vol.95, ST1, Jan., 1969

8) Jennings, P.C. : Periodic Response of a General Yielding Structure, J. Eng. Mech. Div., ASCE, Vol. 90 (EM 2), pp. 131 165, April, 1964

9) Wen, Y. K. : Method for Random Vibration of Hysteretic System, J. Eng. Mech. Div. ASCE, Vol. 102 (EM2), pp. 249 263, 1976.

10）宇田川邦明, 高梨晃一, 田中 尚：繰り返し載荷を受け る $\mathrm{H}$ 形鋼梁の復元力特性一その 1 , 定変位振幅繰り返し
載荷時の塑性ヒンジ回転能力, 日本建築学会構造系論文 報告集，第 264 号，pp. 51 59，1978 年 2 月

11) Baber, T. T. and Wen, Y. K. : Random Vituration of Hysteretic Degrading Systems, J. Eng. Mech. Div. ASCE, Vol. 107 (EM6), pp. 1069 1087, Dec. 1981

12) Kannan, A.E. and Powell, G. H. : A General Purpose Computer Program for Dynamic Analysis of Inelastic Plane Structures with User's Guide, Report No. EERC 73-6 and EERC 73-22, Earthquake Engineering Research Center, Univ, of California, Berkeley, April, 1973

13）高梨晃一, 孟 令樺, 福島暁男, 桑村 仁, 鈆木孝彦: 低 YR 60 キ口級高張力鋼 Beam-Column の耐力と変形能 力, 日本建築学会構造工学論文集, Vol. 36 B, pp. 399 408,1990 年 3 月

14）近藤日出夫ほか 5 名：低 YR 60 キ口級高張力銅柱の耐震 性能, 日本建築学会大会学術講演梗概集, pp. 1357 1358, (中国) 1990 年 10 月

15) Takanashi, K., Meng, L. H. and Simeonov, B. : Static and On-line Earthquake Response Tests on 3 Story Frame of A Low-Yield-Ratio Steel, Bulletin of Earthquake Resistant Structure Research Center, Institute of Industrial Science, Univ, of TOKYO, No.22, pp.33 42, March, 1990

16）陳 以一, 近藤日出夫, 大井謙一, 高梨罗一：複合応力 状態における $\mathrm{H}$ 形鋼柱の耐力劣化現象 その 2 解析報告, 日本建築学会関東支部研究報告集, pp. 101 104, 1991 年

17) Tanahashi, R. et al. : To the Final State of Rectangulear Frames, Proc., 4 th WCEE 2, A-4, pp. 179 194, Santiago Chili, 1969

18）石田修三ほか 3 名：弾塑性骨組の静的大たわろ解析にお ける変位增分法の解技法, 日本建築学会近畿汥部研究報 告集, pp. 333 336, 1986 年

(1991 年 11 月 8 日原稿受理, 1992 年 4 月 13 日採用決定) 